\title{
Analysis on Project-Driven Teaching Method
}

\author{
Ye tao, Chen wei \\ Wuhan Institute of Physical Education Wuhan, Hubei, China \\ 12416010@qq.com; 18778720@qq.com
}

Keywords: project-driven teaching method, constructive, multimedia-aided

\begin{abstract}
Learning theories' development has brought teaching modes' improvement. Project-driven teaching method is just a new teaching mode which is based on the modern constructive learning theory. It emphasizes people-oriented, student-centered and project research. Applying the project-driven teaching method properly will improve the teaching effectiveness and promote interaction between students and teachers. By using of method of literature study and observation, this paper analyzes characteristics and theoretical basis of Multi-media Assisted project-driven teaching method, and based on this constructs effective ways of applying this mode.
\end{abstract}

\section{INTRODUCTION}

Project-driven teaching method was pioneered by McMaster University in Canada. After introduced, this mode has been widely used in foreign countries and achieved good effects. Project-driven teaching method advocates people-centred and with the help of multimedia and network technology can effectively optimize learning environment and improve students' ability of practice and creativity. Applying the project-driven teaching method in cultural teaching is also beneficial to activate the subject consciousness of learning and consistent with the overall trend in education reform.

\section{THEORETICAL BASIS OF PROJECT-DRIVEN TEACHING METHOD}

Large-scale education reforms are guided by certain learning theories and based on those, evolve different teaching modes.

One of the earliest important learning theories could be traced back to behaviorism's stimulus-response theory in the late 19th century. Behavioral learning theory in that period had produced a strong influence on teaching mode. It emphasizes learning is the connection between stimulus and response and view the students as the receiving object of knowledge. But after nearly two decades, because of its inherent limit, it had given way to the cognitive learning theory. It views learners as a unique individual and emphasizes the cognitive structure of individuals. Although it relative to behaviorism's stimulus-response theory had been greatly improved, the cognitive learning theory also had some inherent deficiencies: They neglect human's social and cultural attributes. As psychologists have deepened the research on the rule of the human learning process in recent years, an important branch of learning theory named constructivism is gaining popularity in the West. Constructivism learning theory gives a clear direction to education reform and will inevitably bring changes of teaching mode.

\section{A. Constructivism Learning Theory}

Constructivism theory assumes that world is an objective reality, but every person has their own understanding of the whole world. The process of learning is not only a memory process but also a process of understanding and constructing new knowledge on the basis of existing experience through communicating with the outside world. Constructivism learning theory emphasizes student-centered and students' active exploration, discovery and construction of knowledge. Therefore, "situation”, “collaboration”, “communication” and "construction of meaning” are the key elements of constructivism learning theory. Project-driven teaching method is just based on the constructivism learning theory. 
According to the constructivism learning theory, project-driven teaching method views that student is the main body of information processing not the passive recipient of external stimulus; teacher is a designer, mentor and collaborator not a initiator and inculcator of knowledge. So firstly, teaching must be conducted in real situations and teachers play the role of designers. Teachers create learning scenarios for students and let students take some innovative learning activities in a real environment. Learners can actively and effectively construct knowledge in certain social and cultural background. Secondly, in the class teaching, teachers play the role of mentors and collaborators. They will guide students to study independently and cooperate with students to complete learning tasks in appropriate time, rather than simply imparting knowledge to learners in one-way process. Learners achieve their own meaning construction of knowledge in the learning process through the interaction between teachers and students, students themselves, students and teaching resources.

\section{B. Constructivism theory of cognitive tools}

Another important idea of constructivism theory is about cognitive tools. Theory of cognitive tools considers that in order to make learning process more effectively, it should reduce students' attention time on transmission technology, and pay more concern about teaching technology about how to cultivate learners' thinking in different tasks. Cognitive tools are mental and counting devices to support, guide, and extend learner's thinking process. There are internal tools, including learner's internal cognitive and meta-cognitive strategies, and external tools, including computer-based devices and environment. All these tools are to assist in knowledge construction. According to theories of cognitive tools, making use of external cognitive tools properly can make learners' thinking activities externalizing, and help teachers control and lead their advanced thinking; while rational use of external cognitive tools can activate cognitive and meta-cognitive strategies to promote reflective thinking. Today, the multimedia teaching technology and network technology becomes core of the modern information technologies and also the best and most useful cognitive tools. Supported by multimedia, learners can quickly and easily access a large number of illustrations, vivid true learning resources, and information-rich learning context.

In the guidance of constructivism theory, project-driven teaching method suggest teachers should take learner-centered, create real situations, help learners be more prone to exploratory behaviors and take high-level thinking activities with the multimedia technology assisted.

By reviewing the process of the development of our country's teaching mode, it is rightly based on learning theory's reform. In mid-eighties, China began the reform of teaching mode by the impact of constructivism learning theory, just as project-driven teaching method. It is mainly directed against the traditional teaching mode, emphasizes the guidance of teachers, and constructs a new student-centered and teacher-led teaching mode that take learners' development as main purpose.

\section{PROJECT-DRIVEN TEACHING METHOD’S IMPLEMENTATION}

The terminal effect of learning theory's reform is embodied in the reform of classroom teaching. Classroom is a special place of talents' training. Classroom teaching is an important method to improve their cultural level. Student have the dual task of learning and training, so improving their learning abilities through implementing effective classroom teaching and organizing a wealth of teaching activities is particularly important. Project-driven teaching method based on constructivism learning theory plays an active role in improving the quality of teachers' teaching and the abilities of students' learning. Therefore, project-driven teaching method provides a new way to teaching mode's reform.

Project-driven teaching method takes specific project tasks as learning purposes and takes optimized learning resources as learning medium and the representation of learning production as evaluation tools. Students complete the project that teacher assigned through researching new knowledge themselves to acquire new knowledge. The implementation of the program will be shown as follows.

\section{A. Project Design}

The key point of implementing project teaching mode is choosing the appropriate research project. First, projects should be practical. It can make enable to find the association between the project and the learned course and experience. Second, projects should be educational. They should meet the developmental needs and interests. Moreover, projects should be challenging and instructive. So the 
projects should be combined with features of professional characters. That is, the project should be chosen based on their major, sports.

\section{B. Implementation of the project}

Implementation of the project should be finished by several groups. Students can be divided into several groups according to different situations. The project teams take the special project as the researching subject and learn and explore independently to make self-generated works.

This part can be divided into following steps. First, teacher gives project introduction. Before implementing the project, teacher, as a designer, should set up the correlative situation for students, and describe the project's requirements. Second, students build their project team and make work division. After determining the theme, students can form study teams or choose to complete individually according to their own interests. It should make sure every student in the team have and take different works. Third, students conduct materials' collection and collation. After the work division in a group, students should collect and collate information and materials as many as possible through various ways. Forth, students discuss and research problem-solving ways. Project team should determine problem-solving strategies and methods through group discussion based on further collating, summarizing, digesting, absorbing, and reprocessing the information and materials. In this period, teachers should provide students with targeted advice, guidance and supervision.

\section{Project Reporting and Evaluating}

After preparation works are completed, the project team should display the project's production to the whole class. The forms of final presentation can be various, for example, in text form, such as papers or reports, or the use of computer technology, such as slides, animation, or the use of debates, lectures, drama, and other diverse forms. Then, project evaluation should use multi-agent evaluation, such as student self-assessment, peer assessment, teacher assessment and so on. Evaluation process should be open.

Project-driven teaching method breaks through the idea of traditional teaching's mode. It stimulates the enthusiasm of students through reproducing some situation players are familiar with and achieves mastery of the knowledge and two-way exchange through students' self-learning. In the whole teaching process, it shows not only the leading role of teachers, but also shows the main role of students.

In the context of contemporary education reform, cultural teaching should follow the trend of education reform, combine special learning features and use effective teaching mode to optimize teaching effectiveness and truly improve the qualities.

\section{REFERENCES}

[1] Beckett, Gulbahar H. “Teacher and student evaluations of project-based instruction,” TESL Canada Journal, 2002, vol.19, no. 2, pp. 52, 2001.

[2] Dongjing, Dong guoyong, Guoming. On The Current Situation and Development of “Combining Physical Training with Physical Education” In China. Journal of Anhui Sports Science, 2006, no. 6.

[3] Li Shanhua. Study on Development Countermeasures for Integration of Sports and Education in Schools. Sichuan Sports Science, 2005, no.4.

[4] LI An-na. Educational equity and educational efficiency in "Combination of education and sport”. Journal of Physical Education, 2009, vol.16, no. 9.

[5] Liu Chunxian. On the Combination of Sport and Education. Sports Culture Guide, 2010, no.3.

[6] Gong Honglang, Ding Zhengzhu. The item teaching method's in the vocational school teaching study. Science \& Technology Information, 2007, no.14.

[7] Yao Lijuan. Application of Project Teaching Method in Teaching. Journal of Education Institute of Taiyuan University, 2007, vol.25, no. 2. 